\title{
Neoliberalism and the Dynamics of Capitalist Development in Latin America
}

James Petras and Henry Veltmeyer

An analysis of the dynamics of capitalist development over the last two decades has been overshadowed by an all too prevalent "globalization" discourse. It appears that much of the Left has bought into this discourse, tacitly accepting globalization as an irresistible fact and that in many ways it is progressive, needing only for the corporate agenda to be derailed and an abandonment of neoliberalism. This is certainly the case in Latin America where the Left has focused its concern almost exclusively on the bankruptcy of "neoliberalism", with reference to the agenda pursued and package of policy reforms implemented by virtually every government in the region by the dint of ideology if not the demands of the global capital or political opportunism. In this concern, imperialism and capitalism per se, as opposed to neoliberalism, have been pushed off the agenda, and as a result, excepting Chavéz's Bolivarian Revolution, the project of building socialism has virtually disappeared as an object of theory and practice.

In this paper we would like to contribute towards turning this around-to resurrect the socialist project; to do so by deconstructing the discourse on "neoliberal globalization" and reconstructing the actual contemporary dynamics of capitalist development. 
This is a major task requiring a closer look at the issues. The modest contribution of this paper is to bring into focus the imperialist dynamics of capitalist development in Latin America. To this end, we present an analytical framework for an analysis of the dynamics of capitalist development and imperialism. We then summarize these dynamics in the Latin American context. Our argument is that the dynamics of capitalist development and imperialism have both an objective-structural and a subjective-political dimension and that a class analysis of these dynamics should include both. This means that it is not enough to establish the workings of capitalism and imperialism in terms of their objectively given conditions that affect people and countries according to their class location in this system. We need to establish the political dynamics of popular and working class responses to these conditions- to neoliberal policies of structural adjustment to the purported requirements of the new world order. The politics of the Left might so be better informed.

\section{The Neoliberal Era of Capitalist Development and Imperialism}

Capitalist development in Latin America can be periodized as follows: (1) an initial phase of primitive accumulation and national development dating more or less from the Independence Movement in the 1860s and crystallizing in the Porfiriato, an extended dictatorship of the big landowners and incipient bourgeoisie in Mexico; (2) a period of modernization, incipient industrialization (in the form of "Fordism") and social reform, dating from the Mexican Revolution in the second decade of the twentieth century; (3) a period of state-led capitalist development with "international cooperation" (technical and financial assistance) dating from the end of the Second World War and the construction 
of the Bretton Woods world order (1945-70); (4) a period of transition (1971-82) characterized by an extended crisis in the global system of capitalist production and diverse efforts to restructure the system; and (iv) the construction of a new world order designed so as to free the "forces of freedom" from the constraints on capital accumulation imposed by the system of sovereign nation states. This phase, which can be dated from the onset of a region-wide debt and an ensuing "development" crisis, is characterized by dynamic processes of neoliberal globalization and imperialism - the institution of a neoliberal policy framework (the structural adjustment program, as it was termed at the time), a renewed imperial offensive, and the decline but then partial recovery of the capital accumulation process and the self-styled "forces of economic and political freedom".

The latest period of capitalist development has two dimensions (globalization in theory / imperialism in practice, forces of opposition and resistance), both of which can also be broken down into four phases.

\section{Neoliberalism and Imperialism in Practice: A Framework of Analysis}

Phase I (1975-82) of the neoliberal project is associated with the bloody Pinochet regime in Chile constituted with a military coup in 1973. The "bold reforms" implemented by this regime and extended into Argentina and Uruguay were subsequently implemented by Margaret Thatcher and Ronald Reagan, and used by economists at the World Bank as a model for the structural reforms set as the price of admission into the new (neoliberal) world order. 
Phase II (1983-90) of neoliberalism (imperialism masked as globalization) includes the foundation stones of renewed process of capital accumulation on a global scale; setting the parameters for a new configuration of economic and political power; implementation of a second round of neoliberal "structural reform"; launch of an ideology (globalization) designed to legitimate this reform process, and the first wave of privatizations as part of this reform process; and a process of redemocratization designed as a means of securing the political conditions of structural adjustment—a marriage of strategic convenience between capitalism /economic liberalism and democracy / political liberalism (Dominguez and Lowenthal, 1996).

Phase III (1990-2000) entails what might be viewed as a "golden age" of massive transfers of public property to the "private sector" (capitalists and their enterprises); an enormous net outflow of capital ("international resource transfers") in the form of profits on investments, debt payments and royalty charges; virtually no economic growth—less than one percent per capita over the decade and a growing divide in the distribution of society's wealth and income; huge bailouts of the banks and investors in corporate stock in a situation of financial crisis; and another round of neoliberal policy reform ("structural reform"), this time with a "human face" (adding to the reform process a "new social policy" targeted at the poor,); a second wave of privatizations and an associated denationalization of the banks and strategic economic enterprises; and a post-Washingron Consensus on the need for a more inclusive form of neoliberalism designed to empower the poor (Craig and Porter, 2006; Ocampo, 1998; Van Waeyenberge, 2006).

Phase IV (2000-09) begins with an involution in the system of capitalist production and the collapse of foreign direct investment inflows; and the onset of political crisis viz. widespread disenchantment with neoliberalism, and a process of 
regime change (Argentina, Bolivia, Ecuador, Brazil, Uruguay, Venezuela—a coup against and the restoration of Chávez to power-and Uruguay. In 2003, the production crisis gives way to a mild economic recovery for a number of countries in the region and a sweeping realignment of political forces into four blocs. The basis of this process of economic and political development is a realignment of global production-a primary commodities boom fueled by the growing demand in China and India for new sources of energy, natural resource industrial inputs and consumption goods for a rapidly growing middle class.

\section{Opposition to Imperialism, Class Rule and Neoliberalism: Forces of Resistance}

Phase 1 (1973-82) of the anti-neoliberal project includes a major counter-offensive of the landed proprietors and big capital against the incremental advance of the workers and peasants; a double-offensive of the state against the rural poor and landless peasants in the form of the "Alliance for Progress" ("rural development") and use of the state's repressive apparatus against the guerrilla armies of national liberation; the counteroffensive of capital, with the support of the state, against the working class, resulting in a disarticulation of the labor movement, cooptation of its leadership and a weakening in its capacity to negotiate for higher wages and better working conditions; and, with the agency and support of U.S. imperialism, the institution of military coups and the institution of military rule and a war against "subversives" under the aegis of a Washington-designed "Doctrine of National Security".

Phase II (1983-99) was characterized by a reorganization of the popular movement, particularly in the countryside —in the indigenous communities and among 
the masses of dispossessed, landless workers and peasant producers; the mobilization of the forces of popular opposition and resistance against the neoliberal policies of the governments of the day; various uprisings of indigenous peasants in Ecuador, Chiapas and Bolivia, resulting in the ouster of several presidents if not regime change, and in the blocking of governments efforts to extend the neoliberal agenda; the division of the indigenous movement (in Bolivia and Ecuador) into a social and political movement, allowing it to contest elections as well as mobilize the forces of resistance in direct action against the state; a general advance in the popular movement with the growth of new offensive and defensive class struggles.

Phase III (2000-03), corresponding to a crisis in production and ideology vis-à-vis neoliberalism, was characterized by the emergence of various offensive struggles and social mobilizations that led to the overthrow of regimes in Argentina, Bolivia, Ecuador. In Venezuela, Hugo Chávez came to power, inciting the complex dynamics of a class struggle characterized by a series of counter-offensives by the ruling class (attempted coups, referendums), growing demands for radical reforms and the institution of the "Bolivarian Revolution" based on an anti-imperialist strategy designed to take the country along a socialist path.

As for Phase IV (2003-09) it saw the rise of a bloc of pragmatic neoliberal, quasipopulist democratic socialist regimes oriented towards the post-Washington Consensus, an ebb in the flow of the popular movements, the radicalization of Chávez's project of "21st Century Socialism" and the reflux of the popular movement. 


\section{Four Cycles of Neoliberalism}

"Neoliberalism" in this historic context denotes a national policy—or rather, reform of the then-existing policy of state-led development ("structural reform" or "structural adjustment")_-justified with a neoclassical theory of economic growth and development and an ideology of globalization. In this context, we can identify four cycles of neoliberal "structural reform". The first cycle, initiated by the Chicago Boys in Chile under Pinochet . After this first round of neoliberal experiments in policy reform, extended to Argentina and Uruguay, crashed in the early 1980s, a second round of neoliberal policy reforms was implemented under conditions of redemocratization, an external debt crisis and the political leverage that this crisis provided the World Bank and the IMF, the agencies that assumed primary responsibility for implementing the Washington Consensus on needed policy reform.

The third cycle of neoliberal policies was implemented in the 1990s. At the outset only four major regimes had failed to fully embrace the "discipline" of structural adjustment. But serious concerns had surfaced as to the sustainability of the neoliberal model and the associated Washington Consensus. For one thing, neoliberalism had utterly failed to deliver on the promise of economic prosperity and mutual benefits to countries north and south of the global development divide. For another, structural reforms had not only released the "forces of freedom" but also forces of resistance that threatened the survival not only the viability of the neoliberal model but the survival of the state itself. To avert an impending crisis the ideologues of globalization and neoliberal architects of policy reform came up with a revised model: structural adjustment with a human face (UNICEF, 1989) in one formulation, productive 
transformation with equity (ECLAC, 1990) in another, and "sustainable human development" (UNDP, 1996) in yet another. The common feature of these and other such models was a continuing commitment to a neoliberal program of "structural reform" at the level of national policy, the design and adoption of a "new social policy" that "targeted" social investment funds at the poor and their communities, and specific policies that helped shelter the most vulnerable groups from the admittedly high "transitional" social costs of structural adjustment. ${ }^{1}$

\section{Policy Dynamics of Neoliberal Structural Reform}

The discourse on "globalization" emerged in the 1980s in the context of efforts in policymaking circles to renovate the ailing Bretton Woods world order-to create a "new world order". Under widespread systemic conditions of a capitalist production crisis and an associated fiscal crisis, economists at the World Bank and its sister "international financial institutions", all adjuncts of the U.S. imperial state, formulated a program of policy reforms designed to open up the economies of the developing world to the forces of "economic freedom", to integrate these societies and economies into the new world order. These policy reforms included various IMF stabilization measures such as currency devaluation and import restrictions, and policies of structural adjustment: (1) privatization of the means of social production and associated economic enterprises (reverting thereby the nationalization policies of the earlier model of state-led development); (2) deregulation of diverse product, capital and labor markets; (3) liberalization of capital flows and trade in products and services; and (4) and administrative decentralization, attempting to "democratize" thereby the relation of civil 
society to the state, transferring to local governments in partnership with civil society responsibility for economic and social development; that is, privatizing "development" (allowing the poor to "own" and be responsible for improving their lives, changing themselves rather than the system.

By the end of the 1980s, this package of policy reforms had transformed the economic and social system of many Latin American societies. The state-led reforms of the 1960s and 1970s (nationalization, regulation of capitalist enterprise and capital inflows, protection of domestic producers, rural credit schemes, land and income redistribution market-generated incomes, etc.) had been reverted, effectively halting, where not reversing, the process of development and incremental change.

The outcome and social impacts of this social transformation were all too visible and apparent, especially to those groups and classes that bore the brunt of the adjustment and globalization process. With a significant reduction in the share of labor (and households) in society's wealth and national income, and an equally significant concentration of asset-based incomes and its conversion into capital, Latin American society became increasingly class divided and polarized between a small minority of individuals capacitated and able to appropriate the lion's share of the new wealth and a large mass of producers and workers who had to bear the costs of this "structural adjustment" and excluded from its benefits. The economic and political landscape of Latin American society was, and is, littered with the detritus of this development process. The objectively given conditions of this process are not only reflected in the all too evident deterioration in living and working conditions of the mass of the urban and rural population. They are also reflected in the evidence of a process of massive outmigration, the export of labor as it were, and an equally massive process of capital export-a net 
outflow or transfer of "financial resources" estimated by Saxe-Fernandez and Núñez (2001) to amount to over USD 100 million for the entire decade of the 1990s. Recent studies suggest that if anything the process, fuelled by the financialization of development and policies of privatization, liberalization and deregulation, has continued to accelerate, putting an end to any talk, and much writing, about a purported "economic recovery" based on a program of "bold reforms" and "sound economics." Neoliberalism is in decline if not dead.

\section{Globalization or Global Class War?}

It is commonplace among many intellectuals, pundits and policy makers both in Latin America as elsewhere to discuss "globalization" as of it were a process unfolding with an air of inevitability, the result of forces beyond anyone's control—at worst allowing policymakers to manage the process and at best to push it in a more ethical direction; that is, allow the presumed benefits of globalization to be spread somewhat more equitably. This is, in fact, the project shared by the antiglobalization movement in their search for "another world" and the pragmatic centre-left politicians currently in power in their search for "another development".

In this discourse, globalization appears as a behemoth whose appetites must be satisfied and whose thirst must be quenched at all costs—costs borne, as it happens but not fortuitously, by the working class. In this context to write, as do so many on the Left today, of the "corporate agenda" and "national interests", etc. is to obfuscate the class realities of globalization— the existence and machinations of the global ruling class (Petras, 2007) and what Jeffrey Faux (2006) terms a "global class war". 
Faux's book allows us to view in a different way the globalizing economy, the politics and economics of free trade, and soaring corporate profits on the one hand, and, on the other hand, deteriorating standards of living and the continuing (and deepening) poverty of most of the world's people. What is behind this reality? A dynamic objective process, working like the invisible hand of providence through the free market to bring about mutual benefits and general prosperity? Or a class of people who in their collective interest have launched a global war with diverse features and theaters. One feature of this class war, one of many (on its manifestation in the European theater, see Davis, 1984; and Crouch and Pizzorno, 1978) entails ripping up the social contract that had allowed the benefits of capitalism to be broadly shared with other social classes. Another feature was the use of the state apparatus to reduce the share of labor in national income waken its organizational and negotiating capacity, and repress any movement for substantive social change.

The globalization discourse hides the class realities behind it. The press, for example, consistently talks about national interests without defining whom exactly is getting what and how, under what policy or decision-making conditions. Thus, American workers are told that the Chinese are taking their jobs. But the China threat, in fact, is but another global business partnership, in this case between Chinese commissars who supply global capital cheap labor and the U.S. and other foreign capitalists who supply the technology and much of the capital used to finance China's exports. Workers in Latin America are told that it is their inflexibility and intransigence, and government interference in the free market, that hold them back from engaging meaningfully or at all in the many benefits of globalization. Many, including on the Left, view "globalization" in this way. However, it would be better to see it for what it is: a class project vis-à-vis 
the accumulation of capital on a global scale; and as "imperialism" vis-à-vis the project of world domination, a source and means of ideological hegemony over the system.

Neoliberalism is the reigning ideology of the global elite, a transnational capitalist class that holds its annual meeting in the plush mountain resort of Davos, Switzerland. Hosted by the multinational corporations that dominate the world economy (Citigroup, Siemens, Microsoft, Nestlé, Shell, Chevron, BP Amoco, Repsol-YPF, Texaco, Occidental, Halliburton, etc.), some 2000 CEOs, prominent politicians (including former and the current presidents of Mexico), this and other such meetings allow this elite to network with pundits and international bureaucrats, discuss policy briefs and position papers on the state of the global economy, and to strategize abut the world's future - all over the best food, fine wine, good skiing and cozy evenings by the fire among friends and associates - fellow self-appointed and nominated members and guardians of the imperial world order.

Davos is not a secret cabal, although it is surrounded by meetings and workings of a host of groupings, meetings and committees and extended networks that is. Journalists issue daily reports to the world on the wit and informal charm of these unelected, selfappointed or nominated members of the class that runs and manages the global economy. In this sense it is a political convention of what Fauz dubs "the Davos Party" that includes solid representation from the economic and political elite in Latin America. The mechanism and dynamics of class membership are unclear; as far as we know it has not been systemically studied. But it likely involves "people" like Henrique Fernando Cardoso, former dependency theorist and later neoliberal president of Brazil, upon or before completion of his term in office, being invited to give a "talk" or address members of the imperial brain trust, the global elite, at one of its diverse foundations and "policy 
forums", such as the Council on Foreign Relations (CFR), a critical linchpin of the imperial brain trust and its system of thinktanks, policy forums and geopolitical planning centers. Certainly this is how former Mexican presidents Carlos Salinas and Ernesto Zedillo were appointed and assigned specific responsibilities on diverse working "committees" designed to identify and redress fissures in and threats to the system. It is evident that listing in Forbes' listing of the world's biggest billionaire family fortunes, such as Bill Gates, George Soros and Carlos Slim, is sufficient in itself to ensure automatic membership in the club.

The New World Order system easily identifies those members of the global elite in each country that, as Salbuchi (2000) notes, are "malleable, controllable and willing to subordinate themselves to the system's objectives". Their careers are then launched so that they may rise to become presidents of their countries or ministers of finance and central bank governors. This was the case, for example, for Argentina's Domingo Cavallo, Chile's Alejandro Foxley and Brazil's Henrique Cardoso, each of whom received suitable local and international press coverage; were honored with "prestigegenerating" reviews, interviews, conferences and dinners, etc.; and then invited to address the Council on Foreign Relations, the Americas Society and Council of the Americas, so that the key New World Order players in New York and Washington could evaluate them. If and when they pass muster their election campaigns are generously financed by the corporate, banking and media infrastructure of the "establishment" that has the resources and means to bring them to power legally and democratically—to do the bidding of their masters and colleagues. ${ }^{2}$ Some are even invited to join elite circles and organizations such as Trilateral Commission and the Carnegie Endowment for International Peace), or one of the CRC's working committees. 


\section{The Left Responds to the Crisis of Neoliberalism}

Throughout the 1990s the dominant popular response to neoliberal globalization and associated regimes and policies was in the form of social movements that represented and advanced most effectively the struggle against what Ron Chilcote (1990) called a "plurality of resistances to inequality and oppression". These movements placed growing pressure from below on the regime and the "political class". However, by mid-decade, well into the left's general retreat from class politics, a number of these movements followed Brazil's labor movement (The PT or Workers' party) in establishing a party apparatus to allow them to contest both national and local elections - to pursue an electoral strategy. This political development did not require or mean an abandonment of the social movement strategy of social mobilizations, etc. but it did open up a broader opportunity to participate in the electoral process, allowing the populace to participate in party politics.

\section{Local Politics and Community Development}

The mobilization of the electorate via the institutional trappings of liberal democracy provided a new impetus to the political left—-the segment that opted for party politics over social mobilization as a strategy for achieving state power: influencing government policy from within rather than outside the system. However, a large swath of the Left seem to have heeded Jorge Casteñeda's call for the Left to switch its electoral ambitions to the municipality, local politics and community development. His argument, advanced in Utopia Unarmed, was that "municipal politics should be the centre-piece of the left's 
democratic agenda... because it typifies the kind of change that is viable... a stepping stone for the future" (1994: 244). Engagement in local politics, he argued -and much of the left seemed to have followed this line-would provide the basis for a consolidation of the Left after the so-called “democratic transition" from 1979 (Bolivia, Ecuador) to 1989 (Chile). In addition it would help re-articulate the civil society-local state nexus and restore legitimacy to the Left's relationship with the popular sector (Lievesley, 2005: 8).

An example of the approach proposed by Casteñeda, and in fact widely pursued by the Left even before his book (the World Bank's strategy in this regard was already quite advanced) had already is the PT's experience with municipal government in Porto Alegre, the capital city of Brazil's state of Rio Grande do Sul (1989-2004). The PT administration opened up municipal institutions with a stated commitment to accountability and transparency, as well as citizen participation in the budget planning process via the mechanism of public meetings (Orçamento Participativa).

The Porto Alegre experience with participatory budgeting was hailed by the World Bank and the International Development "community" of multilateral institutions and liberal academics as a good example of collective decision-making for the common good, a model of grassroots participatory development and politics, and it continues to serve as a guide to similar practices and experiences elsewhere (Abers, 1997). Other examples of this "participatory" approach towards local politics and community development, widely adopted by the Left in the 1990s in its retreat from class, can be found in Bolivia and Ecuador, both countries a laboratory for diverse experiments to convert the municipality into a "productive agent" (the "productive municipality") 3 and exertions by the Left to bring about social change via local politics (North and Cameron, 2003). On the left this shift from macro-politics and development (national elections 
versus social movements) to micro-politics and development (local politics, participatory development) was viewed as a salutary retreat from a form of analysis and politics whose time had come and gone. Within academe the dynamics of this process has been viewed in some circles as the harbinger of a "new tyranny" (Cooke and Kothari, 2001).

\section{The World Social Forum Process: Is Another World Possible?}

On January 3, 2007, Caracas, the capital city of an epicenter of social and political transformation in the region was concerted into the Mecca of the international left. Thousands of activists (100, 00 according to the organizers) arrived in Caracas from some 170 countries to participate in the sixth edition of the World Social Forum (WSF), a process initiated in Porto Alegre, Brazil, six years earlier. It was the first of a then thereafter annual event, extended to and replicated in other regional settings from India, Europe and most recently Nairobi, Kenya in the African subcontinent. In each place and in each annual event, the organizers would bring together hundreds of nongovernmental and civil organizations committed to the search for a more ethical form of globalization, a more human form of capitalism. The process brings together diverse representatives of a self-defined new left committed to the belief in the necessity and possibility of a "new world", an alternative to globalization in its neoliberal form.

There are, of course, defined limits to this new political process: participants are invited and expected to explore diverse proposals for bringing about "another world" but to limit this search to reforms to the existing system, reforms that no matter how "radical" are expected to leave the pillars of the system intact. This liberal reform orientation to the process is ensured by explicit exclusions—any political organizations that include armed 
struggle or violent confrontation and class struggle in its repertoire, that are oriented towards revolutionary change.

ATTAC, a Paris-based social democratic organization is the most visible representative of this approach towards social change, but the World Social Forum from its inception morphed into and became a significant expression of what emerged as the "antiglobalization movement". This movement had its origins in the encounter of diverse forces of resistance formed in middleclass organizations in the "global north" and mounted against the symbols of neoliberal globalization such as the World Trade Organization and the G-7/8 annual summit. A defining moment in this movement, rooted in the organizations of the urban middle class-NGOs, unions, students, etc.-in both Europe and North America, included the successful mobilization against the MAI in Seattle. This mobilization was the first of a number of serialized events scheduled to unfold at important gatherings of the representatives of global capital-Genoa, Quebec, Melbourne, Dakar....

In Latin America the World Social Forum process, is the basic form taken by the "antiglobalization movement" in the search for "another world" (the latest event in this process was hosted by Lula, taking place in Bélem towards the end of January 2009). Apart from the absence of an internal division between the advocates of moderate reform (ethical globalization) and more radical change the antiglobalization process is designed to define and maintain the outer limits of permitted change; that is, controlled dissent from the prevailing model of global capitalist development. Not anti-globalization but a more ethical form. Not anti-capitalism but a more humane form of capitalism, a more sustainable human form of development. Not anti-imperialism because imperialism is not at issue. 


\section{The New Left and the Politics of No-Power}

In the shape and form of class struggle the path towards social change in the 1960s and 1970s was paved with state power. That is, the forces of resistance, at the time based in the countryside, in the organizations and movements of the landless and near landless peasants, and in the urban-based organized labor movement; and for the most part led by petit-bourgeois middle class intellectuals, were concerned with the capture of state power. In the 1990s, in a very different context—neoliberal globalization-and in the wake of the Zapatista uprising in January 1994, there emerged on the left a postmodern twist to the struggle for social change: "social change without taking state power" (Holloway, 2002).

In the discourse of Subcomandante Marcos, the Zapatismo came to symbolically —or theoretically, in the writings of Holloway and others (for example, Burbach, 1994) —represent a "new way of doing politics": to bring about social change without resort to class struggle or the quest for state power (Holloway, 2002). However, much of the Latin American Left appeared all o ready to retreat from class politics and engage the new way of "doing politics". Some of the Left joined the struggle for change at the level of local politics and community development-to bring about social change by building on the assets of the poor, their "social capital" (Portes, 1998, 2000; Ocampo, 2004). Another part joined the "situationists" and other militants of "radical praxis" in an intellectual engagement with the forces of social and political disenchantment in the popular barrios of unemployed workers-in Gran Buenos Aires and elsewhere (Besayag and Sztulwark. 2000; Colectivo Situaciónes, 2001, 2002). This was in the early years of the new millennium. In the specific conjuncture of economic and political crisis, a generalized 
rejection of the "old way" of doing politics ("que se vayan todos"), the search for redemption and relevance left a large part of the left without a political project, without a social base for their politics.

\section{Dynamics of Electoral Politics: What's Left of the Left}

With the advent of the new millennium, it was clear that the neoliberal model even in its revamped form, had failed to deliver on its promise of economic growth and general prosperity. Instead it had deepened existing class and global divides in wealth and income, and regime after regime was pushed towards its limits of endurance by the forces of popular mobilization. In this context, the political class in each country turned to the left, opening up new opportunities for groups that had hitherto concentrated their efforts on local politics and community development. Governments of the day, many of them neoliberal client regimes of the US, fell to the forces of resistance and opposition.

Political developments in the region regarding this regime change led to a concern in the US, and widespread hopes and expectations on the Left, about a tilt to the left in national politics and what the press (Globe \& Mail) has termed a "disheartening" triumph of politics over "sound economics". A lot of this concern revolves around Hugo Chávez, who appears (to the press and U.S. policymakers) to be taking Venezuela down a decidedly anti-US, anti-imperialist and seemingly socialist path-and taking other governments in the region with him.

Chávez's electoral victory was seen by many as the moment when a red tide began to wash over the region's political landscape. In the summer of 2002, the Movement to Socialism (MAS) in Bolivia, led by militant coca growers' leader Evo 
Morales, became the second largest party in the Congress while in December it achieved huge victories in municipal elections-in what was billed by the MAS itself as "la toma de los municipios". The election to state power of Lula da Silva in Brazil (October 2002) wa followed by Nestor Kirchner in Argentina (May 2003), Tabaré Vasquez in Uruguay (November 2004), Evo Morales (December 2005), (December 2006) Rafael Correa in Ecuador (December 2006) and most recently Lucas Longo in Paraguay. The tide was checked in Mexico in the summer of 2006 when Lopez Obrador, presidential candidate of the PRD, fell just short of victory, and in Peru, where the nationalist Humala lost out to Alan Garcia, the once disgraced social democrat but reborn neoliberal. But it appeared to swell again with Daniel Ortega's victory in Nicaragua—although, given his opportunism and religious rebirth, Ortega could hardly be viewed as on the Left notwithstanding his friendship with Chávez and Fidel Castro—and Rafael Correa.

Thus it appeared that Latin America had turned against the US-inspired—and dictated—neoliberal policies of structural adjustment and globalization by electing to state power a number of parties on the political left—although "moderate" or "pragmatic". Centre-left regimes, some of which cherish their links with Cuba and relish throwing it in the face of the U.S. administration, which has shown itself to be extraordinarily ideological and non-pragmatic, now outnumber right-of-centre governments in the region. The days of the US-supported and instigated right-wing dictatorships and military rule are over, having long disappeared in the dustbins of history and replaced by a new breed of neoliberal regimes. 


\section{Latin America turns left?}

These regimes in appearance (that is, as constructed in the rhetoric of public discourse) have changed or are changing economic course, ostensibly moving away from the neoliberal policies pushed by the US. This was the case in Argentina, for example where the Kirchner administration was compelled by the most serious economic and political crisis in its history to confront the IMF and the World Bank, and the US, by halting payments on the country's external debt, redirecting import revenues towards productive and social investments, including short-term work projects demanded by the mass of unemployed workers that at the time constituted over $25 \%$ of the laborforce and who had taken to the streets, picketing highways in protest. The result: some three years later is an annual growth rate of $8 \%$, the highest in the region.

Another example of apparent regime change was in Brazil, where and when in October 2002 the electorate after his third attempt voted Ignacio [Lula] da Silva, leader of the PT, into power, re-electing him in 2006 to a second term in office. The first President on the "left" voted into power since Allende in 1970, Lula is nevertheless (and for good reason, it turns out) very well received by Wall Street, if not Washington, which tends to view him as a thorn in the U.S. side. Indeed Lula played a major role in defeating the White House plan for a hemispheric free trade zone, and continues to annoy the U.S. with his support of Chávez-Morales-Correa axis in Latin American politics. In this context, the intellectual Left associated with the antiglobalization movement choose to see Lula as an opponent of neoliberal globalization. In fact, Lula, on behalf of Brazil's agribusiness and other capitalist producers simply has been playing and continues to play hardball in negotiations over access to the U.S. market. 
Elections of centre-left governments followed in Uruguay (2004), Chile (2005), Ecuador (2006) where the electorate was polarized between a business magnate, Alvaro Noboa, the richest man in the country and a committed neoliberal ideologue; and Rafael Correa, head of a centre-left coalition that appears to be taking Ecuador down the same path as Evo Morales is taking Bolivia, particularly in regard to a constituent assembly that might well, or is expected to, change the economic and social system as well as the correlation of class forces in the country's politics. In this regard, elements of the political left in Ecuador, especially those associated with the "Coordinadora de Movimientos Sociales" (CMS), see a political opportunity to build a "radical bloc" on the basis of combined action "from above" (the government) and "from below" (the indigenous and popular movement). Whether this will happen (see Saltos, 2006) ${ }^{4}$ remains to be seen. For one thing, it hinges on the capacity of the popular movement for active mobilization - to pressure the Correa government from below towards the left. On this the historic record is fairly clear. As observed by Pedro Stedile, leader of the MST, "without active mobilization the government gives nothing".

With the election of Rafael Correa over Alvaro Noboa the popular and indigenous movement in Ecuador at least placed on the agenda of government action issues such as national sovereignty, nationalization of the country's natural resources, agrarian reform, indigenous rights, subordination of payment on the external debt to social programs, renegotiation of oil contracts will the multinationals, the ending of the military bases in Manta, and Latin American (vs. continental) integration. Whether the government will act on these issues remains to be seen.

The conflict that ensued over the Constituent Assembly (CA) in Ecuador and Bolivia, where the CA was finally approved) is symptomatic of the profound legitimation 
crisis in the system of class domination in these and other countries (Saltos, 2006). Earlier and other forms of hegemony, such as "globalization" and the trappings of representative "democracy", have lost their hold over people, having been totally undermined by the all too tangible and visible signs of the negative effects of neoliberal policies. The reign of Washington in the region appears to be in serious decline. Nor can Washington, in its efforts to preserve the status quo or the status quo ante, revert to the use of force-to bring back the Armed Forces to restore order. Its only recourse is to engage "civil society" in the project of "good governance"- to restore political order by means of a broad social consensus that reaches well beyond the state and the political class (Blair, 1997; OECD, 1997; UNDP, 1996; World Bank, 1994b).

What we saw in Quito and La Paz in regard to the Constituent Assembly went beyond a conflict between two branches of government. At issue was that those who elected Correa and Morales had come to the point of refusing to be subordinated to a state controlled by the dominant class and servile to Washington and the interests of global capital. On achieving political representation with the election of Morales and Correa, and Chávez for that matter, the forces in the popular movement were all too aware that the legislature was dominated by the "oligarchy" (the ruling class is understood in Bolivia and Ecuador). In this situation, Morales and Correa were compelled to construct a multi-class alliance and mobilize the forces of resistance to class rule and the neoliberal agenda of previous governments under the post-Washington Consensus. The result is the construction of a multi-ethnic or pluri-national state oriented towards what the VicePresident of Bolivia, Alvaro Garcia, conceives of as an Andean form of capitalism, and a new anti-american axis of regional politics and trade. 
These and other such political developments in Bolivia and Ecuador are illustrative of what appears to be a regional trend. For example, in neighboring Colombia in October 2003 the voters elected a former union leader Luis Garzón as mayor of Bogotá. The election marked a swing to the left in Colombia's second most important elective office, a clear challenge to the pro-US, scandal-ridden right-wing government of Alvaro Uribe. If we take these and other such developments together, especially in Venezuela, Bolivia and Ecuador, there does indeed seem to be a leftward swing in the political winds of change, leading ...to declare that democratic elections are not enough: governments in the region also have to "govern democratically", i.e. place no constrictions on the forces of opposition to the new agenda in national and regional politics.

\section{Whither Socialism in a Sea of Crisis and Neoliberal Decline?}

A serious discussion of the prospects for socialism in Latin America today must take into account world economic conditions in the current conjuncture, the state of US-Latin American relations relative to the project of world domination and imperialism, the specific impact on Latin American countries of these conditions and relations, the conditions deriving from the correlation of class forces within these countries, and the class nature and agency of the state relative to these forces. 


\section{World Economic Conditions and Their Impact on Latin America}

Latin America's "restructured" capitalist economy emerged from the financial crisis of the 1990s and the recession of the early years of the new millennium with its axis of growth anchored in the primary sector of agro-mineral exports (Cypher, 2007; Ocampo, 2007). From 2003 to 2008 all Latin American economies, regardless of their ideological orientation or political complexion, based their economic growth strategy on the "reprimarization" of their export production, to take advantage thereby of the expanding markets for oil, energy and natural resources and the general increase in the price of primary commodities on the world market. The driving force of capitalist development in this period was agribusiness and mineral exports, export-oriented production of primary commodities leading to an increased dependence on diversified overseas markets and a change in the correlation of class forces, strengthening the right and, notwithstanding a generalized tilt to the Left at the level of the state, a weakening of the Left. Ironically, the primarization of exports led to the revival and strengthening of neoliberalism via the reconfiguration of state policy to favor agro-mineral exporters and accommodate the poorest section through populist clientelistic "poverty programs". In the context of a primary commodities boom and the emergence of a range of democratically elected centre-left regimes, trade union leaders were coopted and the social movements that had mobilized the forces of resistance to neoliberalism in the 1990s were forced to beat a retreat from the class struggle (Petras and Veltmeyer, 2009).

The link between U.S. finance capital, the growth of industry and the domestic market in Asia, and the primary commodities boom, was responsible for the period of high growth in Latin America from 2003 to 2008, when the boom went bust and most 
economies in the region succumbed to a financial crisis of global proportions and a system-wide deep recession that threatened to push the U.S. economy, at the centre of the gravitational force of this crisis, towards collapse. With the U.S. empire's "overextension" and the exceedingly high costs of prosecuting imperialist war in Iraq and maintaining its enormous military apparatus-military expenditures on the Iraq war alone increasing by millions each minute (as of February 17, 2009 US $\$ 597.7$ billion) and likely to cost well over a trillion dollars before it is over-the capacity of the U.S. to weather the storm of financial crisis and a deepening recession has been seriously diminished. Given the absorption of the U.S. state in the Iraq war, governments in Latin America in the latest phase of capitalist development managed to achieve a measure of "independence" and "relative autonomy" in their relations with the United States. And this has given leaders like Hugo Chavez a free hand in his efforts to push Venezuela in a socialist direction.

\section{Impact of World Recession and U.S. Imperial Revivalism in Latin America}

Latin America is feeling the full brunt of the world recession. Every country in the region, without exception, is experiencing a major decline in trade, domestic production, investment, employment, state revenues and income. The projected growth of Latin America's GDP in 2009 has declined from 3.6\% in September 2008 to 1.4\% in December 2008 (Financial Times, January 9, 2009). More recent projections estimate Latin America's GDP per capita as falling to minus two percent (-2\%). ${ }^{5}$ As a result state spending on social services will undoubtedly be reduced. State credit and subsidies to big banks and businesses will increase; unemployment will expand, especially in the agro- 
mineral and transport (automobile) export sectors. Public employees will be let go and experience a sharp decline in salaries. Latin America's balance of payments will deteriorate as the inflow of billions of dollars and euros in remittances from overseas workers, a major source of "international financial resource" for many countries in the region, declines. Foreign speculators are already withdrawing tens of billions of investment dollars to cover their losses in the U.S. and Europe. A process of foreign disinvestment has replaced the substantial inflow of "foreign investment" in recent years, eliminating a major source of financing for major "joint ventures". The precipitous decline in commodity prices in 2008 , reflecting an abrupt drop in world demand, has sharply reduced government revenues dependent on export taxes. Foreign reserves in Latin America can only cushion the fall in export revenues for a limited time and extent.

The recession also means that the economic and social structure, the entire socioeconomic class configuration on which Latin America's growth dynamic in recent years (2003-2008) was based, is headed for a major transformation. The entire spectrum of political parties linked to the primary commodity export model and that dominate the electoral process will be adversely affected. The trade unions and social movements oriented toward an improvement in their socioeconomic conditions and wages, social reforms and increased expenditures of fiscal resources and social spending within the primary commodity export model will be forced to take direct action or lose influence and relevance.

The initial response of the left of center regimes that came to power in the context of a primary commodities boom and neoliberalism in its demise has largely focused on: (i) financial support for the banking sector (Lula) and lower taxes for the agro-mineral export elite (Kirchner/Lula); (ii) cheap credit for consumers to stimulate domestic 
consumption (Kirchner); and (iii) temporary unemployment benefits for workers laid off from closed small and medium size mines (Morales). The response of the Latin American regimes to date (up to the beginning of 2009) could be characterized as delusional, the belief that their economies would not be affected. This response was followed by an attempt to minimize the crisis, with the claim that the recession would not be severe and that most countries would experience a rapid recovery in "late 2009". It is argued in this context that the existing foreign reserves would protect their countries from a more severe decline.

According to the IMF, $40 \%$ of Latin America's financial wealth ( $\$ 2.200$ billion dollars) was lost in 2008 because of the decline of the stock market and other asset markets and currency depreciation. This decline is estimated to reduce domestic spending by 5\% in 2009. The terms of trade for Latin America have deteriorated sharply as commodity prices have fallen sharply, making imports more expensive and raising the specter of growing trade deficits (Financial Times, January 9, 2009, p. 7).

The impact of these "developments" can be traced out not only in regime politics but on the class structure and the correlation of forces associated with this structure. Thus, the fall in the demand and price of primary commodities is resulting in a sharp decline in income, the power and the solvency of the agromineral exporters that dominated state policy in recent years. Much of their expansion during the "boom years" was debt-financed, in some cases with dollar and euro-denominated loans (Financial Times, January 9, 2009, p.7). But many of the highly indebted "export elite" now face bankruptcy and are pressuring their governments to relieve them of immediate debt obligations. And in the course of the recession/depression there will be a further concentration and centralization of agro-mineral capital as many medium and large 
miners and capitalist farmers are foreclosed or forced to sell. The relative decline of the contribution of the agro-mineral sector to the GDP and state revenues means they will have less leverage over_the government and economic decision making. The collapse of their overseas markets and their dependence on the state to subsidize their debts and intervene in the market means that the "neoliberal" free market ideology is dead - for the duration of the recession. Weakened economically, the agro-mineral elite are turning to the state as its instrument of survival, recovery and refinancing.

In this new context, the "new statism" in formation has absolutely nothing "progressive" about it, let alone any claim to "socialism". The state under the influence of the primary sector elites assumes the primary task of_imposing the entire burden of the recession on the backs of the workers, employees, small farmers and business operators. In other words, the state is charged with indebting the mass of people in order to subsidize the debts of the elite export sector and provide zero cost loans to capital. Massive cuts in social services (health, pensions and education), and salaries will be backed by state repression. In the final analysis the increased role of the state will be primarily directed to financing the debt and subsidizing loans to the ruling class.

\section{The State of U.S. Relations in Latin America in the Current Conjuncture}

If the U.S. suffered a severe loss of influence in the first half decade of the early 2000 s due to mass mobilization and popular movements ousting its clients, during the subsequent four years the U.S. retained political influence among the most reactionary regimes in the region, especially Mexico, Peru and Colombia. Despite the decline of mass mobilizations after 2004, the after-effects continued to ripple through regional relations 
and blocked efforts by Washington to return to relations that had existed during the "golden decade" of pillage (1990-1999).

While internal political dynamics put the brakes on any return to the 1990s, several other factors undermined Washington's assertion of full scale dominance: (i) The U.S. turned all of its attention, resources and military efforts toward multiple wars in South Asia (Afghanistan), Iraq and Somalia and to war preparations against Iran while backing Israel"s aggression against Palestine, Lebanon and Syria. Because of the prolonged and losing character of these wars, Washington remained relatively immobilized as far as South America was concerned. Equally important Washington's declaration of a intensified worldwide counter-insurgency offensive (the "War on Terror") diverted resources toward other regions. With the U.S. empire builders occupied elsewhere, Latin America was relatively free to pursue a more autonomous political agenda, including greater regional integrations, to the point of rejecting the U.S. proposed "Free Trade Agreement".

In this new context the spectrum of international relations between the U.S. and Latin America runs the gamut from "independence" (Venezuela), "relative autonomy" within competitive capitalism (Brazil), relative autonomy and critical opposition (Bolivia) to selective collaboration (Chile) and deep collaboration within a neoliberal framework (Mexico, Peru and Colombia). Venezuela constructed its leadership of the alternative nationalist pole in Latin America, in reaction to U.S. intervention. Chávez has sustained its independent position through nationalist social welfare measures, which has garnered mass support. A policy of "independence" was made possible, and financed as it were, by the commodity boom and the jump in oil prices. The "dialectic" of the USVenezuelan conflict evolved in the context of U.S. economic weakness and over- 
extended warfare in the Middle East on the one hand and economic prosperity in Venezuela, which allowed it to gain regional and even international allies, on the other.

The autonomous-competitive tendency in Latin America is embodied by Brazil. Aided by the expansive agro-mineral export boom, Brazil projected itself on the world trade and investment scene, while deepening its economic expansion among its smaller and weaker neighbors like Paraguay, Bolivia, Uruguay and Ecuador. Brazil, like the other BRIC countries, which include Russia, India and China, forms part of newly emerging expansionist power center intent on competing and sharing with the U.S. control over the region's abundant resources and the smaller countries in Latin America. Brazil under Lula shares Washington's economic imperial vision (backed by its armed forces) even as it competes with the U.S. for supremacy. In this context, Brazil seeks extra-regional imperial allies in Europe (mainly France) and it uses the "regional" forums and bilateral agreements with the nationalist regimes to "balance" its powerful economic links with Euro-US financial and multi-national capital.

At the opposite end of the spectrum are the "imperial collaborator" regimes of Colombia, Mexico and Peru, which remain steadfast in their pro-imperial loyalties. They are Washington's reliable supporters against the nationalist Chávez government and staunch backers of bilateral free trade agreements with the U.S.

The other countries in the region, including Chile and Argentina, continue to oscillate and improvise their policies in relation to and among these three blocs. But what should be absolutely clear is that all the countries, whether radical nationalist or imperial collaborators operate within a capitalist economy and class system in which market relations and the capitalist classes are still the central players. 


\section{Socialism and the Latin American State in the Current Conjuncture of the Class Struggle}

Control of the state is an essential condition for establishing socialism. But it is evident that a more critical factor is the composition of the social forces that have managed to achieve state power by one means or the other. From 2003 to 2008, in the context of a primary commodities boom and a serious decline in the mobilizing power of neoliberal globalization, one state after the other in Latin America has tilted to the Left in establishing a nominally anti-neoliberal regime. However, the only regime in the region with a socialist project is that of Chávez, who has used the additional fiscal resources derived from the sale of oil and the primary commodities boom—specifically the growing world demand for oil - to turn the state in a socialist direction under the ideological banner of the "Bolivarian Revolution". All of the other center-left regimes formed in this conjuncture for one reason or the other, and regardless of their national sovereignty concerns vis-à-vis U.S. imperialism, have retained an essential commitment to neoliberalism, albeit in a more socially inclusive and pragmatic form as prescribed by the post-Washington Consensus (Ocampo, 1998). A surprising feature of these centre-left regimes is that not one of them - again Venezuela (and of course Cuba) the exceptionuse their additional fiscal revenues derived from the primary commodities boom to reorient the state in a socialist direction, i.e. to share the wealth or, at least, in the absence of any attempt to flatten or eliminate the class structure to redirect fiscal revenues toward programs designed to improve the lot of the subordinate classes and the poor. Again, Chávez" is the exception in the use of windfall fiscal revenues derived from the primary commodities boom (oil revenues in the case of Venezuela) to improve conditions for the 
working class and the popular classes. The statistics regarding this "development" (see Weisbrot, 2009) are startling. Over the entire decade of Chávez rule, social spending per capita has tripled and the number of social security beneficiaries more than doubled; the percentage of households in poverty has been reduced by $39 \%$, and extreme poverty by more than half. During the primary commodities boom (2003-2008), the poverty rate in Venezuela was cut by more than half, from $54 \%$ of households in the first half of 2003 to $26 \%$ at the end of 2008. Extreme poverty fell even more (by $72 \%$ ). And these poverty rates measure only cash income, and do not take into account increased access to health care or education. However, in the other countries in the region governed by a centre-ofleft regimes, not one of which is oriented towards socialism, conditions were and are very different. In a few cases (Chile, Brazil) the rate of extreme poverty was cut, but in all cases, despite recourse to an anti-poverty program following the PWC, government spending was relatively regressive. In only one case (Venezuela) is per capita PSE greater today than it was in 2000 in the vortex of a widespread crisis and a zero growth (Clements, Faircloth and Verhoeven, 2007). In many cases social programs and government spending was allocated so as to distribute more benefits to the richest stratum of households and the well to do than to the working class and the poor. ${ }^{6}$ Even in the case of Bolivia, where the Morales-Garcia Lineres regime has a clearly defined antineoliberal and anti-US imperialist orientation, not only has the government not expanded social program expenditures relative to investments and expenditures designed to alleviate the concerns of foreign investors but the richest stratum of households benefited more from fiscal expenditures on social programs than the poorest (Petras and Veltmeyer, 2009). All of the centre-left regimes that have came to power in this millennium, especially Brazil and Chile, elaborated anti-poverty programs with reference to the PWC. 
In the case of Bolivia fiscal expenditures on social programs defined by the "new social policy" of the post-Washington Consensus have been supplemented by a populist program of bonuses and handouts, and popular programs in health and education, but these have been almost entirely financed by Cuba and Venezuela. As for the fiscal resources derived from Bolivia's participation in the primary commodities boom they have been allocated with a greater sensitivity to the concerns of foreign investors than the demands of the working class and the indigenous poor.

In this situation what is needed is not only access to state power, which the social movements managed to ostensibly achieve via the election of Evo Morales, but an ideological commitment of the government to socialism - to turn the state in a socialist direction. In this connection the Chávez regime is unique among Latin American heads of state. Even so the road ahead for the Bolivarian revolution in bringing about socialism of the twenty-first century promises to be long and "rocky", as in the case of Cuba littered with numerous pitfalls but unlike Cuba with the likely growth in the forces of opposition.

\section{Notes}


11. The basic elements of the new post-Washington Consensus policy agenda under the model of "sustainable human development (UNDP, 1996) are: (1) a neoliberal program of macroeconomic policy measures, including privatization, agricultural modernization and labor reform; (2) a "new social policy" supported by a "social investment fund" targeted at the poor; (3) specific social programs (policies related to health, education and employment) designed to protect the most vulnerable social groups from the brunt of the high "transitional" social costs of structural adjustment — and to provide a "human face" to the overall process; and (4) a policy of administrative decentralization and popular participation designed to establish the juridicaladministrative framework for a process of participatory development and conditions of "democratic governance.

22. Of course, this also applies to the U.S. as in the run-up to George W. Bush's campaign for a second term in office. On 28 July, 2004, a caravan of fifty multi-billionaires met in Boston to defend and secure the electoral victory of the president. In the words of Count Mamoni - to a reporter of La Jornada (Jul 28, 2004) "We are the rich who wish to ensure that the president who we bought [paid for] stays in the White House". He adds that "those of us who were born to wealth and privilege ... [are] owners of the country [and must continues as such]." One of the participants in the "Join the Limousine" tour added that "we are all winners under this government, just some a lot more than others".

33. On this see De la Fuente (2001), Sánchez (2003) and Terceros and Zambrana Barrios (2002).

44. Napoleon Saltos, Director of the CMS sees political developments in Ecuador as somewhere between Venezuela, which is implementing from above a sort of socialist plan without pressure from below, and Bolivia, where the government to some extent is subject to the pressures of a mobilized population. 
55. The onset of the recession in Latin America is evident in the $6.2 \%$ fall in Brazil's industrial output in November 2008 and its accelerating negative momentum (Financial Times, January 7, 2009 p. 5).

${ }^{6} 6$. On this point see the IMF as in Alier and Clements (2007: 4-5): "Reallocating social spending to programs that most benefit the poor ... [are] important for forging a more equitable society... [but] the distributive incidence of social spending varies greatly across programs, with primary education and social assistance programs having the most favorable impact, while higher education and social insurance programs tend to benefit middle and upper-income groups. Because of the low share of spending in pro-poor programs - such as social assistance - the majority of social spending benefits accrue to those that are relatively well off."

\section{References}

Abers, Rebecca. 1997. Inventing Local Democracy: Neighborhood Organizing and Participatory Policy-Making in Porto Alegre, Brazil. Ph.D. Dissertation, University of California, Urban Planning.

Alier, Max and Benedict Clements. 2007. "Comments on Fiscal Policy Reform in Latin America," Paper prepared for the Copenhagen Consensus for Latin America and the CaribbeanConsulta de San José, Costa Rica, October 20-25,

Aznar, José María. 2007. América Latina. Una agenda de libertad. Madrid: Fundación para el Análisis y los Estudios Sociales (FAES).

Besayag, Miguel y Diego Sztulwark. 2000. Política y situación: de la potencia wl contrapoder. Buenos Aires: Ed. De Mano en Mano.

Blair, H. 1997. Democratic Local Governance in Bolivia. CDIE Impact Evaluation, No. 3. Washington DC: USAID. 
Booth, David. 1996. "Popular Participation, Democracy, the State in Rural Bolivia," Dept. of Anthropology, Stockholm University. La Paz.

Bulmer-Thomas, Victor. 1996. The New Economic Model in Latin America and its Impact on Income Distribution and Poverty. New York: St. Martin's Press.

Burbach, Roger. 1994. "Roots of the Postmodern Rebellion in Chiapas," New Left Review, 1 (205).

Casteñeda, J. G. 1994. Utopia Unarmed: The Latin American Left After the Cold War. New York:

Chilcote, R. H. 1990. "Post-Marxism. The Retreat from Class in Latin America," Latin American Perspectives, 65 (17), Spring.

Clements, Benedict, Christopher Faircloth and Marijn Verhoeven. 2007. "Public Expenditure in Latin America: Trends and Key Policy Issues," IMF Working Paper WP/07/21.

Colectivo Situaciones. 2001. Contrapoder: una introducción. Buenos Aires: Ediciones de Mano en Mano (Noviembre).

Colectivo Situaciones. 2002. 19 y 20: Apuntes para el nuevo protagonismo social. Buenos Aires: Editorial De mano en Mano, Abril.

CONAIE. 1994. Proyecto político de la CONAIE. Quito.

CONAIE—Confederación de Nacionalidades Indígenas de Ecuador. 2003. Mandato de la I Cumbre de las Nacionalidades, Pueblos y Autoridades Alternativas. Quito: CONAIE.

Cooke, B. and U. Kothari, eds, 2001. Participation: The New Tyranny? London and New York: Zed Books.

Crabtree, John. 2003. "The Impact of Neo-Liberal Economics on Peruvian Peasant Agriculture in the 1990s," Pp. 131-161 in Latin American Peasants, edited by Tom Brass, London, Frank

Craig, D. and Porter, D. 2006. Development Beyond Neoliberalism? Governance, Poverty Reduction and Political Economy. Abingdon Oxon: Routledge.

Crouch, C, and Pizzorno, A. 1978. Resurgence of Class Conflict in Western Europe Since 1968. London: Holmes \& Meier. 
Cypher, James M. 2007. "Back to the 19th Century? The Current Commodities Boom and the Primarization Process in Latin America," Presented to the LASA XXVII International Congress Session ECO20, Montreal, Canada September 5-8.

Dávalos, Pablo. 2004. "Movimiento indígena, democracia, Estado y plurinacionalidad en Ecuador," Revista Venezolana de Economía y Ciencias Sociales, 10 (1), Enero-Abril.

Davis, Mike. 1984. “The Political Economy of late-Imperial America,” New Left Review, 143, January-February. . 2006. Planet of Slums. London: Verso.

De Castro Silva, Claudete y Tania Margarete Keinart. 1996. “Globalizacion, Estado nacional e instancias locales de poder en America Latina," Nueva Sociedad, No. 142, Abil-Mayo.

De la Fuente, Manuel, ed. 2001. Participación popular y desarrollo local, Cochabamba: PROMECCEPLAG-CESU.

De la Garza, Enrique. 1994. "Los sindicatos en America Latina frente a la estructuración productiva y los ajustes neoliberales," El Cotidiano, No. 64, 9-10, Mexico.

Delgado-Wise, Raúl. 2006. "Migration and Imperialism: The Mexican Workforce in the Context of NAFTA," Latin American Perspectives, 33 (2): 33-45.

Dominguez, J. and A. Lowenthal (eds.). 1996. Constructing Democratic Governance. Baltimore: John Hopkins University Press.

ECLAC_Economic Commission for Latin America and the Caribbean. 1990. Productive Transformation with Equity. Santiago, Chile: ECLAC.

Faux, Jeffrey. 2006. The Class War. Washington DC: Economic Policy Institute.

Holloway, John. 2002. Change The World Without Taking Power: The Meaning of Revolution Today. London: Pluto Press.

Holloway, John and Eloina Peláez, eds.1998. Zapatista! Reinventing Revolution in Mexico. London: Pluto Press. 
Levitt, Kari. 2003. "Grounding the Globalization Debate in Political Economy," Notes for a Contribution Towards the publication of Globalization and Anti-Globalization. Halifax: Saint Mary’s University.

Lievesley, Geraldine. 2005. “The Latin American Left: The Difficult Relationship between Electoral Ambition and Popular Empowerment," Contemporary Politics, 11 (1), March. Macas, Luis. 2000. "Movimiento indígena ecuatoriano: Una evaluación necesaria," Boletín ICCI “RIMAY,” Año 3, No. 21, diciembre, pp. 1-5.

Macas, Luis. 2004. “El movimiento Indígena: Aproximaciones a la comprensión del desarrollo ideológico politico,” Tendencia Revista Ideológico Político, I, Quito, Marzo, pp. 60-67.

Marcos, Subcomadante. 1994. "Tourist Guide to Chiapas," Monthly Review

North, Liisa and John Cameron, eds. 2003. Rural Progress, Rural Decay: Neoliberal Adjustment Policies and Local Initiatives Bloomfield CT: Kumarian Press.

Ocampo, A. 2004. "Social Capital and the Development Agenda," pp. 25-32 in Atria, R. et al. eds. Social Capital and Poverty Reduction in Latin America and the Caribbean: Towards a New Paradigm. Santiago: ECLAC.

Ocampo, José Antonio. 1998. "Beyond the Washington Consensus: an ECLAC Perspective," CEPAL Review 66, (December), 7-28. . 2007. "The Macroeconomics of the Latin American Economic Boom," CEPAL Review 93, December.

OECD_Organisation of Economic Cooperation and Development. 1997. Final Report of the DAC Ad Hoc Working Group on Participatory Development and Good Governance. Paris.

Petras, James. 1997a. “The Resurgence of the Left,” New Left Review, No. 223. . 1997b. "MST and Latin America: The Revival of the Peasantry as a Revolutionary Force," Canadian Dimension, 31 (3), May/June. 
. 2001. "Are Latin American Peasant Movements Still a Force for Change? Some New

Paradigms revisited," The Journal of Peasant Studies, 28 (2).

. 2006. "Following the Profits and Escaping the Debts: International Immigration and

Imperial-Centered Accumulation."

. 2007. "Global Ruling Class: Billionaires and How They 'Made It',"

Petras, James and Henry Veltmeyer. 2005. Social Movements and the State: Argentina, Bolivia,

Brazil, Ecuador. London: Pluto Press.

. 2009. What's Left in Latin America. Aldershot: Ashgate Publishing.

Portes, A. 1998. "Social Capital: its Origins and Applications in Modern Sociology," Annual Review of Sociology, 24: 1-24.

.2000. "Social Capital: Promise and Pitfalls of its Role in Development," Journal of Latin American Studies, 32: 529-547.

Salbuchi, Adrian. 2000. El cerebro del mundo: la cara oculta de la globalización. $4^{\text {th }}$. ed., Córdoba, Argentina: Ediciones del Copista.

Saltos Galarza, Napoleón. 2006. “La derrota del poder económico y la emergencia del poder constituyente," Quito, December $1<$ wnsaltosg@yahoo.es>.

Sánchez, Rolando, ed. 2003. Desarrollo pensado desde los municipios: capital social y despliegue de potencialidades local. La Paz: PIED_Programa de Investigación Estratégia en Bolivia.

Saxe-Fernández, John and Omar Núñez. 2001. “Globalización e Imperialismo: La transferencia de Excedentes de América Latina," in Saxe-Fernández et al. Globalización, Imperialismo y Clase Social, Buenos Aires: Editorial Lúmen.

Stedile, Joao Pedro. 2000. Interview with James Petras, May 14.

Terceros, Walter and Jonny Zambrana Barrios. 2002. Experiencias de los consejos de participación popular (CPPS). Cochabamba: PROSANA, Unidad de fortalecimiento comunitario y transversales. 
Toothaker, Christopher. 2007. “Chávez Cites Plan for 'Collective Property',” Associated Press, Posted March 27 [http://www.sun-sentinel.com/business/realestate/sfl-achavez27mar]

UNICEF. 1989. Participación de los sectores pobres en programas de desarrollo local. Santiago, Chile: UNICEF.

UNDP. 1996. "Good Governance and Sustainable Human Development," Governance Policy Paper. http://magnet.undp.org/policy.

Van Waeyenberge, Elisa. 2006. "From Washington to Post-Washington Consensus," in Jomo, K. S. and Ben Fine (eds.) The New Development Economics. London: Zed Books.

Weisbrot, Mark. 2009. “The Chávez Administration at 10 Years: The Economy and Social Indicators," The Center for Economic and Policy Research (CEPR), Washington DC, February 5.

World Bank. 1994a. The World Bank and Participation. Washington DC: World Bank, Operations Policy Department.

World Bank. 1994b. Governance. The World Bank Experience. Washington DC: World Bank. 